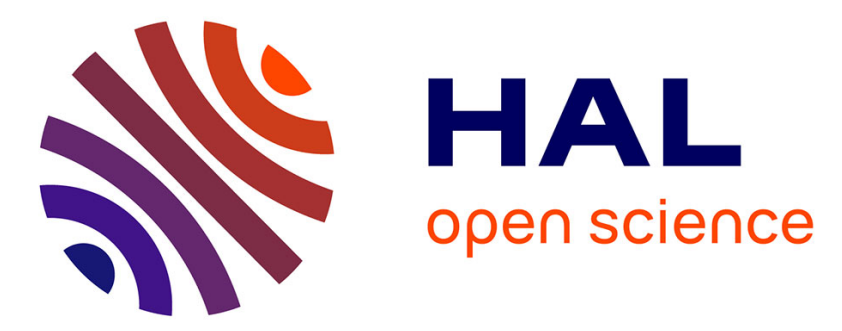

\title{
THERMAL BEHAVIOUR OF Nd-Fe-B ALLOYS STUDIED BY T.E.M.
}

D. Lemarchand, B. Labulle, P. Vigier

\section{To cite this version:}

D. Lemarchand, B. Labulle, P. Vigier. THERMAL BEHAVIOUR OF Nd-Fe-B ALLOYS STUDIED BY T.E.M.. Journal de Physique Colloques, 1988, 49 (C8), pp.C8-637-C8-638. 10.1051/jphyscol:19888288. jpa-00228459

\section{HAL Id: jpa-00228459 https://hal.science/jpa-00228459}

Submitted on 1 Jan 1988

HAL is a multi-disciplinary open access archive for the deposit and dissemination of scientific research documents, whether they are published or not. The documents may come from teaching and research institutions in France or abroad, or from public or private research centers.
L'archive ouverte pluridisciplinaire HAL, est destinée au dépôt et à la diffusion de documents scientifiques de niveau recherche, publiés ou non, émanant des établissements d'enseignement et de recherche français ou étrangers, des laboratoires publics ou privés. 


\title{
THERMAL BEHAVIOUR OF Nd-Fe-B ALLOYS STUDIED BY T.E.M.
}

\author{
D. Lemarchand, B. Labulle and P. Vigier \\ U.A. 808, Faculté des Sciences de Rouen, BP 118, 76134 Mont Saint-Aignan Cedex, France
}

\begin{abstract}
Thinned samples of as-cast and sintered Nd-Fe-B magnets have been observed by transmission electron microscopy during in-situ heat treatments. Strip-like contrast was observed in the $\mathrm{Nd}_{2} \mathrm{Fe}_{14} \mathrm{~B}$ phase. A transition from cubic to hexagonal $\mathrm{Nd}_{2} \mathrm{O}_{3}$ occurs at about $200 \mathrm{C}$.
\end{abstract}

\section{Introduction}

The discovery of boron stabilized $\mathrm{Nd}-\mathrm{Fe}-\mathrm{B}$ compounds has opened the possibility to achieve the goal of low cost high performance permanent magnets. The improvement in magnetic properties of the $\mathrm{Nd}-\mathrm{Fe}-\mathrm{B}$ magnets over the existing high energy $\mathrm{Sm}$ Co based magnets ( $B H_{\max }$ is multiplied by a factor 1.5 ) broaden the range of applications. In addition, the basic raw materials required for the new material have a price advantage and fewer supply restrictions than either $\mathrm{Sm}$ or Co.

However, the development of Nd-Fe-B magnets still shows very unfavorable behaviour at elevated temperatures: for a continue service, the maximum temperature is only $120^{\circ} \mathrm{C}$ while it reaches $300{ }^{\circ} \mathrm{C}$ for 2 : 17 systems. Corrosion and oxidization problems are mainly associated with the free $\mathrm{Nd}$ present in the grain boundary eutectic phase.

The aim of this work is to study the thermal behaviour of as-cast and sintered Nd-Fe-B magnets by in-situ transmission electron microscopy observations.

\section{Experimental procedure and results}

Two compositions: $\mathrm{Nd}_{14.3} \mathrm{Fe}_{77.7} \mathrm{~B}_{8}$ and $\mathrm{Nd}_{16.6} \mathrm{Fe}_{75.4} \mathrm{~B}_{8}$ (atomic percentage) were studied. The ingots elaborated from raw materials containing traces of $\mathrm{Al}, \mathrm{Ca}$, $\mathrm{Mg}$, and Si were prepared in UGIMAG S.A. laboratories. After a vacuum induction melting, the melt was cast into a walled copper mould, then crushed under inert atmosphere and milled to produce a narrow size distribution of particules. The powder was magnetically aligned, pressed, sintered for one hour at $1100^{\circ} \mathrm{C}$ and heat treated. For the TEM observation, specimens were thinned by ion milling and held into the microscope with a heating specimen holder. Thermal treatments were performed in-situ, from room temperature to $600^{\circ} \mathrm{C}$.

The ternary diagram predicts three phases at low temperature for the choosen compositions and we report successively on each one.

a) The main phase $\mathrm{Nd}_{2} \mathrm{Fe}_{14} \mathrm{~B}$, at room temperature, is always found to be free of crystal lattice defects and corresponds to the hard magnetic phase (tetragonal structure, $a=0.880 \mathrm{~nm}, c=1.220 \mathrm{~nm}$ ).

At about $200^{\circ} \mathrm{C}$, it sometimes appears on electron micrographs a strip-like contrast with spacing of about $20 \mathrm{~nm}$ (Fig. 1a). On the corresponding diffraction
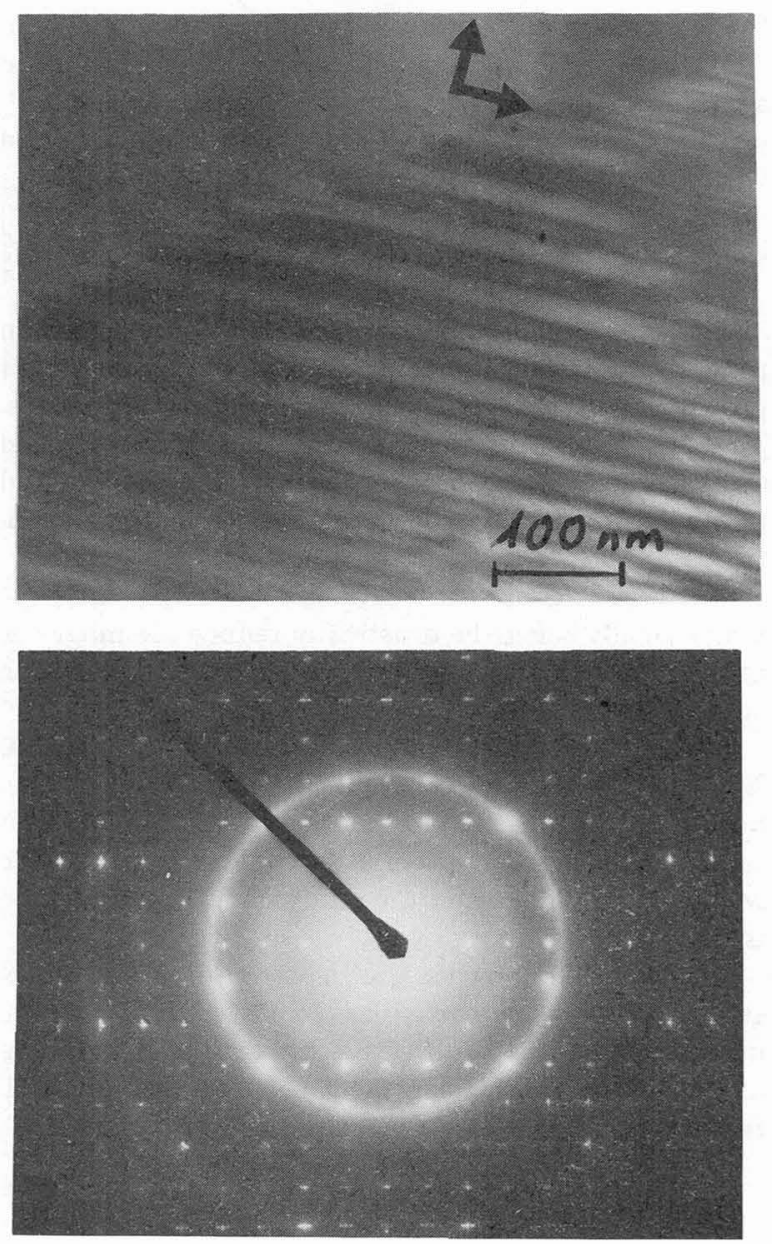

Fig. 1. - (a) Strip-like contrast in the $\mathrm{Nd}_{2} \mathrm{Fe}_{14} \mathrm{~B}$ phase. The $c$-axis of the tetragonal structure is perpendicular to the micrograph plane. (b) Micro-diffraction pattern with satellites connected with the previous stripes; [001] zone axis. 
pattern, satellites of diffraction spots are observed in $[100]^{*}$ and [010]* directions (Fig. 1b). Rings of polycrystalline iron and amorphous Nd oxide appear simultaneously. The precipitation of $\alpha$-Fe seems to result from the oxidization of $\mathrm{Nd}$ in the main phase.

At higher temperature $\left(500{ }^{\circ} \mathrm{C}\right)$, the oxidization of the main phase is very rapid; $\mathrm{Fe}(\mathrm{OH})_{3}$ rings appear while tiny Fe grains coarsen.

b) The secondary phase is paramagnetic with a tetragonal structure. This boron-rich phase $\mathrm{Nd}_{1.1} \mathrm{Fe}_{4} \mathrm{~B}_{4}$ always shows a high crystalline defect density. It remains very stable during the heating treatment.

c) A Nd-rich phase (about $80 \%$ at. Nd and $20 \%$ at. $\mathrm{Fe}$ ) has a FCC structure with $a=0.52 \mathrm{~nm}$. At room temperature, the sesquioxide $\mathrm{Nd}_{2} \mathrm{O}_{3}$ is already present with large diffraction spots indicating a bad crystallisation. Its structure is cubic $(a=1.11 \mathrm{~nm})$ [Ctype]. This oxide is formed during the elaboration of the alloy and also during the thinning of the specimen.

From $200{ }^{\circ} \mathrm{C}$, a new diffraction pattern due to a hexagonal structure allotropic form of $\mathrm{Nd}_{2} \mathrm{O}_{3}$ (A-type) progressively replaces the previous diagram (Figs. 2a and $2 b$ ).

\section{Conclusion}

The modulated or strip-like contrast in the main phase is not explained now, but it is interesting for its possible consequences on magnetization mechanisms. The stripes periodicity $(20 \mathrm{~nm})$ is such that they could strongly interact with the moving domain walls and justify the coercivity by wall pinning previously noticed at the same temperature $\left(200^{\circ} \mathrm{C}\right)[1]$.

The rapid oxidization of $\mathrm{Nd}$ and the precipitation of magnetically soft $\alpha$-Fe drastically reduce the magnetic properties and produce steps in the demagnetization curve of sintered magnets [2].

The phase transition from cubic to hexagonal Neodymium oxide in Nd-Fe-B alloys has not been reported before: In samples containing aluminium, this transformation takes place at lower temperature than without aluminium and the study of this phenomenon is in progress.

We have to emphasize that electron microscopic observations present particular conditions as vacuum, magnetic field of the objective lens, reduced thickness of the samples. The size effect on oxidization was already reported [3].
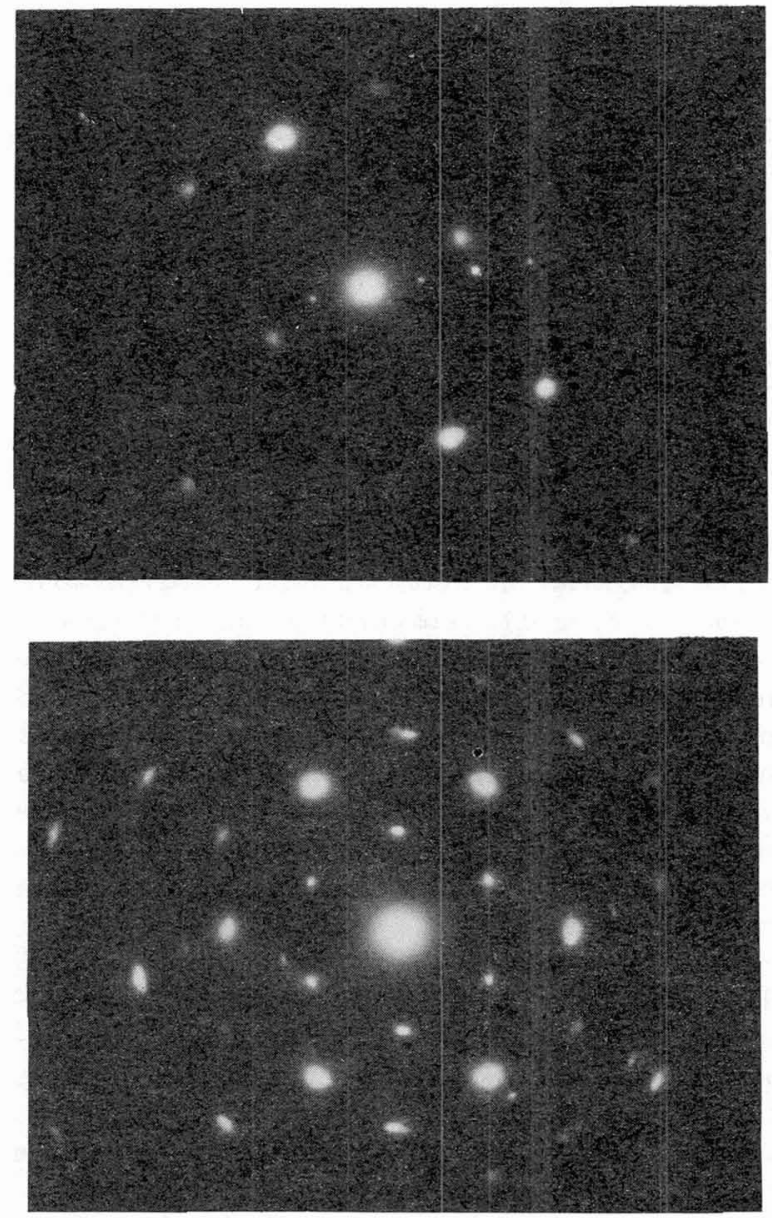

Fig. 2. - (a) $\mathrm{Nd}_{2} \mathrm{O}_{3}$ (C-type), at room temperatures; [112] zone axis. (b) $\mathrm{Nd}_{2} \mathrm{O}_{3}$ (A-type), at $450 \mathrm{C}$, after the phase transition; [0001] zone axis.

\section{Acknowledgments}

We wish to thank UGIMAG S.A. (St Pierre d'Allevard, France) for assistance to prepare samples.

[1] Durst, K.-D., Kronmuller, H., Schneider, G., 5th International Workshop on Magnetic Anisotropy and Coercivity in Rare Earth-Transition Metal Alloys (Bad Soden) 3 sept. 1987.

[2] Givord, D., Tenaud, P., Viadieu, T., J. Appl. Phys. 60 (1986) 3263.

[3] Christodoulou, C. N., Schlup, J., Hadjipanayis, G. C., J. Appl. Phys. 61 (1987) 3760. 